\title{
The Political Non-Apology
}

\author{
Robert M. Eisinger
}

Published online: 12 January 2011

(C) Springer Science+Business Media, LLC 2011

"I apologize if I've offended more people than I usually offend."

New York Jets Coach Rex Ryan

After making a crude comment about Senator Barack Obama during the 2008 presidential campaign, the Reverend Jesse Jackson issued what was characterized in the media as an apology. "For any harm or hurt that this hot mic private conversation may have caused, I apologize." He later added, "I offer apologies because I don't want harm to come to this campaign." Two years later, Congressman Joe Barton (R-TX) also uttered what was widely described as an apology. Barton alleged that the federal government had engaged in a 'shakedown' of the corporation, BP. Barton's words were not well received. He was told "that he needed to apologize immediately, or he would lose his ranking-member seat immediately." Barton responded, "If anything I have said this morning has been misconstrued to the opposite effect, I want to apologize for that misconstrued misconstruction."

Apologies play an important role in society. They maintain the bonds of social relationships, and help solidify some level of trust between public officials and the public at large. Apologies play a similarly important role in electoral politics, but fake, incomplete or insincere apologies threaten to undermine this function of building and sustaining trust between citizens and those that govern.

R. M. Eisinger $(\bowtie)$

School of Liberal Arts, Savannah College of Art and Design, P.O. Box 3142, Savannah, GA 31402, USA

e-mail: eisinger.robert@gmail.com
This paper seeks to commence an analytical discussion about apologies, and specifically the non-apology, because it has received so little attention among political scientists, and because it potentially poses a risk to democracy and its functions. Literature abounds concerning the philosophical roots of apologies, the psychological benefits of providing and receiving apologies, the types of apologies that yield those psychological benefits, apologies as public acts of contrition by governments, and the reparative and retributive effects of those governmental apologies. The term 'apology' is used frequently in the journalistic lexicon, but there is a dearth of scholarly literature about public officials' reactions to scandals, and more specifically, if those public officials are uttering what can best be described as non-apologies. Questions abound concerning non-apologies that demand systematic analysis. Are nonapologies the norm among scandalized public officials, and if so, why? What implications do non-apologies have on political discourse?

Erving Goffman identifies the basic components of an apology as contrition, remorse, recognition of a wrongful act, and a willingness to engage in a "performance of penance" to try to right the wrong that was created. Nicholas Tavuchis defines an apology as requiring "acknowledgement and painful embracement of our deeds, coupled with a declaration of regret." These two definitions of apology have at their core the following characteristics: a succinct addressing of an offense, an expression of remorse, and either an offer of reparations or an assurance that the offense will not be committed again.

Much of what is said today by public officials who have been accused of wrongdoing, while described as apologies, fail to meet these definitions, and instead echo a narcissistic tone in which blame avoidance or victimization mitigates any sense of responsibility or contrition. These utterances, 
labeled as 'non-apologies', enervate the bonds of trust and accountability that exist between the public and its elected officials. The non-apology transcends hortatory and legal speech on which Edelman elaborates. The non-apology is designed to woo constituents, even as it sometimes conceals its emotional appeal. Yet embedded in that emotional appeal is a legalistic framework that intentionally diffuses blame. The result is a unique form of political communication that is neither fish nor fowl. Its ambivalent tone simultaneously seeks to persuade citizens that the future will be better, and that the past should be forgotten.

The implications of the non-apology as a rhetorical tool are vast. Scholars rightfully contend that gerrymandering and demographic sorting largely contribute to the continued high re-election rates of members of Congress. While there is also an ample literature about the effects of congressional campaigns, there is less analysis of how certain words uttered by public servants influence public's views about politics generally. That is, what impact if any does rhetoric uttered by members of congress, scandalized or otherwise, have on citizens' conceptualization. It is also possible that non-apologies contribute to declining and middling levels of trust in government. It may not merely be the scandal that enervates trust, but also the political communications from the public official to his and her constituents.

\section{What is a Non-Apology?}

Aaron Lazare identifies eight characteristics of what he calls a "pseudo-apology." According to Lazare, a pseudoapology 1) offers a vague and incomplete acknowledgement of the offense; 2) uses the passive voice; 3) makes the ostensible offense conditional; 4) questions whether the victim has been harmed or damaged; 5) minimizes the offense; 6) uses the empathic "I'm sorry" (e.g., "I'm sorry you were offended.'); 7) apologizes to the wrong party; or 8) apologizes for the wrong offense. A statement with some but not all of these traits escapes the painful steps of restitution, and of making good for committing a wrong.

I use "non-apology" in lieu of "pseudo-apology" in order to convey more clearly that such statements should not be labeled as actual apologies. Illustrative examples of various non-apologies abound; they come in various forms, shapes and sizes. The failure to acknowledge an offense is a standard form of non-apology. Rather than simply ignoring the offense, offering a vague or incomplete acknowledgement is a more subtle way of attempting to escape blame. In July 2007, the phone number of Senator David Vitter (R-LA) was found in the phone records of Deborah Jeane Palfrey, the "D.C. Madam" who was charged with running prostitution ring in Washington. Vitter ostensibly apologized for his actions, but never mentioned what they were.
He suggested his misdeeds were a thing of the past, and that it was time to move on. "[My wife] Wendy and I dealt with this personally several years ago. I confronted it in confession and marriage counseling, I believe I received forgiveness from God, I know I did from Wendy." Not wanting to describe the offense may be understandable, but failing to acknowledge why an apology is necessary both defeats the apology's purpose, and suggests that the wrongdoer may not appreciate what egregious acts he has committed.

The passive voice is another common trope of the nonapology, and the phrase "mistakes were made" is its most frequent manifestation. In his 1987 State of the Union address, President Reagan addressed his decisions which lead to the Iran-Contra scandal: "But though we've made much progress, I have one major regret: I took a risk with regard to our action in Iran. It did not work, and for that I assume full responsibility. The goals were worthy. I do not believe it was wrong to try to establish contacts with a country of strategic importance or to try to save lives. And certainly it was not wrong to try to secure freedom for our citizens held in barbaric captivity. But we did not achieve what we wished, and serious mistakes were made in trying to do so." In a similar instance, responding to criticism of Democratic fundraising practices widely viewed as improper and possibly illegal, President Bill Clinton conceded that "mistakes were made," but that policy decisions had not been influenced by fundraising practices. Simply admitting that "mistakes were made" fails to acknowledge what the mistakes were, who was responsible, and what will be done to ensure such mistakes will be avoided in the future.

One of the more common types of non-apology is the conditional apology. "If I offended Arab Americans, I regret my choice of words." Such were the words of Congressman John Cooksey (R-LA), referring to a suggestion he made in the wake of September 11 that airport security officials single out anyone "with a diaper on his head." In addition to thinking that only Arab-Americans would be offended by his remarks, Cooksey's non-apology implied that his regret was contingent on their taking offense. Genuine remorse is not contingent on whether someone took offense.

Questioning whether the victim was damaged and minimizing the ostensible offense are two other characteristics enumerated by Lazare. When Congressman Gerry Sikorski (D-MN) and his wife were found to have written hundreds of bad checks, the congressman said that he and his wife regretted their actions, "despite the fact that we were told that holding checks was standard operating procedure, and despite the fact that no taxpayer's money was involved." Similarly, when Senator Bob Kerrey (D-NE) apologized in 1996 for calling President Bill Clinton "an unusually good liar," the Senator could not help adding that "once in print," his offending comment 
"looks a lot worse than it actually is." In both instances, the utterance intentionally and unambiguously trivializes the misdeed, revealing both a lack of understanding and lack of contrition on the part of the offender.

Perhaps the most misused phrase in non-apologies is "I'm sorry." This is because, as Lazare points out, the empathic "I'm sorry" (e.g., "I'm sorry you had a bad day") can be used to strike the chord of apology without assuming any responsibility for the offense. Whereas the empathic "I'm sorry" merely expresses regret that harm was done, an apologetic "sorry" (e.g., "I'm sorry for having done this") implies responsibility for the offense. In the former instance, the person is simply expressing sympathy for the victim; in the latter, the person is taking responsibility for the harm done and expressing remorse.

After being criticized for publicly predicting that Supreme Court Justice Ruth Bader Ginsburg would die within a year, Senator Jim Bunning (R-KY) quickly issued a statement saying he apologized "if my comments offended Justice Ginsbourg [sic]." The hastily-crafted press release - which misspelled the justice's name - expressed regret that Ginsburg may have been unsettled by the morbid prediction, but no regret for the prediction itself.

Bunning offered another non-apology in 2004, after he was criticized for comparing his potential Democratic opponent's appearance to that of Saddam Hussein's sons. Addressing the backlash, Bunning's campaign manager said, "We're sorry if this joke, which got a lot of laughs, offended anyone." The implication of Bunning's statement is that the joke was funny, favorably received, and therefore not really worthy of genuine contrition.

\section{Evidence from Scandalized Politicians}

Statements of all House and Senate members who faced formal disciplinary action from Congress during the 20th Century were analyzed in order to determine the frequency with which non-apologies were made. Such disciplinary actions include expulsion and censure in the Senate, and expulsion, censure, and reprimand in the House. From 1900 to 2000 , thirty-two members faced a disciplinary vote. [In 1907 Senator Reed Smoot (R-UT) was charged with Mormonism, and by extension, acts of polygamy and disloyalty to the United States. The vote to expel him from the Senate failed. Due to lack of sufficient archival data, this case was not included.]

Based on the statements issued by the individual or his spokesperson regarding the offense, each case was put into one of three categories: (1) A full apology; (2) A nonapology; or (3) A Denial/did not apologize. Full apologies include acknowledging the offense, taking responsibility, and either offering a form of recompense, or assuring the offended parties it would not happen again. Non-apologies reflect one or more of Lazare's qualifications for a pseudoapology, including (a) passive or conditional phrasing; (b) self-victimizing; or (c) minimizing the offense. The third category-Denial/Did not apologize-encompasses two types of responses. Denial is when the person does not admit wrongdoing and insists on his or her innocence; Did Not Apologize includes cases where the person does not refute the accusations, but also does not give an apology. Did Not Apologize also includes cases where the person neither accepts nor denies responsibility. Denial of an apology, especially by someone who does not believe that he has committed an act of wrongdoing, is substantively different from the non-apology, both politically, psychologically and philosophically, and not explored here.

I first aim to discern the quality and quantity of genuine and artificial apologies by scandalized members of Congress. I then investigate how the media described the congressional rhetoric. Using Lexis-Nexis, reading newspaper (New York Times, Washington Post, and when available, the largest regional newspaper from the congressperson's home state) descriptions of the comments in order to see if the congressional rhetoric was deemed an apology.

Of the thirty-two individual cases of formal congressional disciplinary action in the 20th century, members of Congress responded by offering insincere, equivocating or otherwise non-genuine apologies. Eleven congressmen (34.4\%) gave non-apologies. Nineteen (59.4\%) either denied the charges or did not apologize; and only two (6.3\%) offered apologies that fulfilled the definition of an apology.

Of the eleven members of Congress who gave a nonapology, nine ran for re-election, and four of the nine (44.4\%) won re-election. Of the nineteen that that either denied the charges or did not apologize, fifteen ran for re-election, and nine of the fifteen $(60 \%)$ won re-election.

One of the non-apologies was offered by Georgia Senator Herman Talmadge (D-GA), who was denounced by the Senate for financial misconduct in 1979. Reading a statement from the Senate floor, he said, "I stand before you firmly criticized...but I am not found guilty of intentional, wrongful, unlawful conduct. There is no recommendation of censure." "I deeply regret my negligence," he continued. "If I could relive the past, I would handle matters differently. I would not delegate so many financial responsibilities to my aides." By stressing that his actions were not intentional, that they were due to neglect and to the errors of others, and by emphasizing that his punishment could have been worse, Senator Talmadge went to great lengths to minimize his offense.

When then-Speaker of the House Newt Gingrich (R-GA) was reprimanded for financial impropriety in 1997, the 
closest he came to apologizing was in a statement he gave on the occasion of his reelection as Speaker: "Let me say to the entire House that 2 years ago when I became the first Republican Speaker in 40 years, to the degree I was too brash, too self-confident, or too pushy, I apologize. To whatever degree in any way that I have brought controversy or inappropriate attention to the House, I apologize."

Gingrich fails to specify what he did without fully acknowledging his responsibility. Similarly, in 1990, the Senate denounced David Durenberger (R-MN) for financial misconduct. In his speech to colleagues, Durenberger said he was "sorry" five times, but his language was less than convincing. "I recognize that real damage has been done by what has been perceived as my desire to push the limits and take advantage of the Senate," he said, "and for that I am deeply sorry."

Among scandalized politicians, denial remains a common rhetorical tool. Rep. Adam Clayton Powell (D-NY) was arguably the master of the 20th century, congressional victimized, denial. Powell revealed his litigious sense of morality by proclaiming, "As long as it's within the law, it's not wrong." Accused of high absenteeism and financial impropriety, Powell's responded by mounting a spirited offense against his critic, Senator John Williams (R-DE). Powell noted that Senator Williams' resort property had restrictive covenants that barred ownership from non-Aryans. According to a February 21, 1963 New York Times article, Powell stated that he was "convinced 'unequivocally' that attacks by Mr. Williams and others were based on the fact that he [Powell] is a Negro." Powell argued that extensive overseas travel at the public's expense was a widespread practice among members of both houses of Congress, and therefore no apology was needed. A New York Times editorial asked Powell to be more contrite, but Powell refused.

Combining victimizing with denial was employed by Congressman Robert L.F. Sikes (D-FL), who on April 7, 1976 was accused of maintaining a conflict of interest between his private business and his legislative duties as the Chairman of the House Military Construction Subcommittee. In a written statement to the Ethics Committee, Sikes wrote, "I am confident that an inquiry will bring out the truth, something the liberal media and the liberal lobby organizations have failed to do in their year-long attempt to destroy me politically."

After being reprimanded by the House Ethics Committee, Sikes gave his first post-reprimand speech at the dedication ceremonies of the Bay County Memorial Medical Center in Panama City, in which he defended himself without a trace of admitting guilt or wrongdoing. "I was even contemplating not seeking re-election this year. I wanted to come home to Florida and enjoy life for a change-go hunting and relax. But I wasn't going to let the liberal eastern establishment press run me out of office. A man, you know, has to preserve his personal integrity." Sikes successfully won his Democratic primary with over $75 \%$ of the vote, ultimately winning without Republican opposition in the 1978 general election.

Examples of sarcastic or blatantly insincere nonapologies include former congressman James Traficant (D-OH), who once called his House colleagues "political prostitutes," and then told a reporter, "I want to apologize to all the hookers in America who I offended by referring to them alongside House members." A few years later, his colleague Tom DeLay (R-TX), after suggesting that there would be retribution against federal judges for what he believed was the mishandling of the Terri Schiavo case, noted that he, "[s]aid something in an inartful way, and I shouldn't have said it that way, and I apologize for saying it that way. It was taken wrong. I didn't explain it or clarify my remarks, as I'm clarifying them here. I am sorry that I said it that way, and I shouldn't have."

These findings, albeit with a small data set, suggest that few congresspersons who are embroiled in scandals articulate apologies as defined by Lazare and Goffman. The congressional scandal data reveal that statements are posed as apologies, without showing genuine remorse or specifying wrongdoing.

\section{Potential Explanations for Non-Apologies}

When faced with the question of whether or not to apologize, public servants often choose political expediency over thoroughness and contrition. However there may be a more fundamental reason why genuine apologies are scarcely uttered. Whereas outright denial often generates attention ("Congressman X denies any wrongdoing") and may invite further scrutiny, a pure apology ('It's all my fault, I'm so sorry") may increase political and legal liability.

Given the limited number of scandalized politicians who utter apologies, a quantitative comparative analysis will not yield statistically significant results. However the limited evidence suggests that non-apologies potentially restore the reputation of the accused. The 1983 congressional page scandal illustrates how different political rhetoric contributed to different political outcomes. In 1983, Congressmen Dan Crane (R-IL) and Gerry Studds (D-MA) were summoned to the floor of the House of Representatives and censured for having sexual relationships with House pages. Studds admitted to a homosexual affair with a seventeen-year-old House page, and apologized for his "error in judgment," but simultaneously portrayed himself as an injured party. Studds told the public that as a gay man forced to stay in the closet, he was a victim of a society hostile to his sexuality. "It is not a simple task for any of us to meet adequately the obligations of either public or 
private life, let alone both. But these challenges are made substantially more complex when one is, as am I, both an elected public official and gay." Studds also claimed that he was a victim of privacy invasion, announcing that the investigation surrounding him "raises fundamental questions with respect to the right to privacy and procedural fairness."

Studds successfully used his non-apology to recast himself not as the perpetrator of an inappropriate sexual relationship, but as the victim of societal bigotry and privacy invasion. For Studds, the strategy garnered political dividends. Although he was formally censured, Studds won re-election with over $55 \%$ of the vote, and went on to serve in Congress until he retired in 1996.

Compare Studds' non-apology to Crane's admitting to an affair with a 17-year-old female page. Crane issued a statement that read, "I'm sorry that I made a mistake. It happened 3 years ago. I'm human, and in no way did I violate my oath of office. I only hope my wife and children will forgive me." Crane's constituents viewed the scandal as evidence of hypocrisy on Crane's part. He had developed over his career a reputation as an outspoken moralist and had supported Ethics Committee's inquiries concerning the House page sex allegations ("If they can prove it, I hope they sock it to them and throw them out," he once said of philandering colleagues). Crane's was defeated in his reelection bid the following year.

The Studds-Crane examples reveal that there is variance among non-apologies. Both Congressmen Studds and Crane uttered non-apologies as defined by Lazare. Crane however was less equivocating; he sought forgiveness, and unlike Studds, made no attempt to blame society or portray himself as a victim. Although both offenders admitted to the charges and both were censured, only one was re-elected: the one who used the scandal to cast himself as a victim.

Non-apologies yielding political rewards are also found in comments by 2003 California gubernatorial candidate Arnold Schwarzenegger. Faced with mounting allegations of sexual misconduct, Schwarzenegger addressed the topic in front of a crowd of supporters the week before the election. "Let me tell you something," Schwarzenegger said. "A lot of [what] you see in the stories is not true, but at the same time, I have to tell you that I always say, that wherever there is smoke, there is fire. That is true. So I want to say to you, yes, that I have behaved badly sometimes," he continued. "Yes, it is true that I was on rowdy movie sets and I have done things that were not right which I thought then was playful, but now I recognize that I have offended people. And to those people that I have offended, I want to say to them I am deeply sorry about that and I apologize because this is not what I'm trying to do." Schwarzenegger vague and incomplete acknowledgment of his offense was an attempt to minimize its importance.
Schwarzenegger's non-apology effectively and successfully killed the story, ending the did-he-or-didn't-he speculation in the press that threatened to distract his campaign in its final weeks. Although his opposition was unmoved, Schwarzenegger's statement addressed the issue of sexual harassment by admitting wrongdoing as he simultaneously deflected blame.

\section{Implications of the Non-Apology}

There are potential political and social costs to the proliferating non-apology. One argument is that if politicians can absolve their sins with a carefully constructed press release, then there is little incentive for them to behave appropriately. The acceptance of the non-apology, one would argue, should accompany continued behavior that demands genuine apologies. Furthermore, as the definition of remorse expands to include equivocations and self-victimizing excuses, as politicians become more willing to use denials and digressions as a way to escape blame, and as the public increasingly responds to these nonapologies with a shrug instead of an outcry, the ties of accountability that bind democratic politicians to their electorate are weakened. The non-apology therefore can be described as a negative influence on the already tenuous bonds between citizens and their government. The public should know the difference between real and false apologies, and demand the former. Doing so it can be argued will promote greater accountability from politicians by raising the price of illicit behavior.

The non-apology phenomenon may also present a cyclical problem. Politicians are more likely to engage in illicit behavior if voters are unwilling to punish them, as evidenced by the high re-election rates of scandalized, nonapologetic congresspersons. Politicians' bad behavior heightens the public's cynicism toward politicians, which in turn may entervate political participation, making the public less likely to punish the bad behavior.

Alternatively, a more sanguine interpretation of the congressional non-apology data is that non-apologies abound, but that they are not on the rise. Given the low and declining levels of newspaper readership, congressional rhetoric, and the media's reactions to it, are not likely to have a significant or substantive impact on constituent behavior or attitudes. Additionally, some scandalized congresspersons who utter non-apologies and lose re-election; non-apologies hardly guarantee electoral success.

The norm of scandalized congresspersons uttering nonapologies should alarm us. While some scandalized seek not to apologize with defiance because they maintain their innocence, and others believe they fear the negative legal 
repercussions that may ensue if their public admittances of guilt find themselves before aggrieved parties, larger questions remain about how non-apologies appear to be a cottage growth industry, especially in the political sphere. Although this article focuses on members of Congress, they are far from the only perpetrators of the non-apology. In 2006, Bridgeport, Connecticut, Mayor John Fabrizi admitted to alcohol and cocaine abuse, regretting "if I have, in any way, hurt the dignity of this office." He assured the audience that his addiction "never affected my job performance" and added, "All I can do is use my office to the benefit of others in making them aware that even people in my position can become victims of drugs and alcohol." Further research demands a critical investigation of how non-apologies differ by type of public servant and officeholder, and the proximity of the scandal to the date of re-election. That is, an elected official with 4 years before his reelection may react with more or less candor than one whose reelection is days or weeks away.

Future non-apology research also demands comparative analyses among representative democracies. Unique cultures of shame, pride, honor, individualism and litigiousness, combined with the variance in how democratic citizens perceive their elected officials, scandalized or otherwise, provide ample hypothesis to test. Crossnational analyses of scandalized political rhetoric would illuminate the extent to which the non-apology transcends boundaries and regimes.

Finally, celebrities are now partaking in non-apologetic discourse. After committing a flagrant foul in the 2006 World Cup, football star Zinedine Zidane "ask[ed] for forgiveness from all the children who watched that," he said. "There was no excuse for it. I want to be open and honest about it. . . I do apologize but I don't regret my behavior because regretting it would mean he was right to say what he said." Just as troubling was the July 13, 2006 New York Times headline that read "A Contrite Zidane Apologizes, but Says His Family Was Slurred." To describe Zidane as contrite and apologetic is to redefine the terms being used; Zidane's response also demands analysis to discern the extent to which the non- apology has become a part of the journalistic vernacular for the celebrities beyond the political sphere.

In She Wore a Yellow Ribbon, John Wayne said to his young cavalry, "Don't apologize-it's a sign of weakness." Apologies do not right all wrongs, nor are they panaceas for mitigating social ills. But apologies serve an important function - to the wronged, and to society as a whole. As Martha Minow notes, "Apologies may restore some dignity, but not the lives as they existed before the violations."

What public figures say matters-for democratic theory and practice. The non-apology is not going way. But the lack of candor in failing to admit guilt and express contrition should be cause for concern. Representative democracy demands levels of trust between the polity and those who govern. As levels of trust in government ebb, we should consider why. Perhaps it is because we the people are listening.

\section{Further Reading}

Goffman, E. 1971. Relations in public: Microstudies of the public order. New York: Basic Books.

Kort, L. F. 1975. What is an apology? Philosophical Research Archives, 1, 80-87.

Lazare, A. 2004. On apology. New York: Oxford University Press.

Minow, M. 1998. Between vengeance and forgiveness. Boston: Beacon.

Schlenker, B. R., \& Darby, B. W. 1981. The use of apologies in social predicaments. Social Psychology Quarterly, 44(3), 271-278.

Slansky, P., \& Sorkin, A. 2006. My Bad: 25 years of public apologies and the appalling behavior that inspired them. New York: Bloomsbury.

Smith, N. 2008. I was wrong: The meanings of apologies. New York: Cambridge.

Tavris, C., \& Aronson, E. 2007. Mistakes were made (but not by me): Why we justify foolish beliefs, bad decisions, and hurtful acts. New York: Houghton Mifflin Harcourt.

Tavuchis, N. 1991. Mea Culpa: A sociology of apology and reconciliation. Stanford: Stanford University Press.

Robert M. Eisinger is Dean of the School of Liberal Arts at the Savannah College of Art and Design. 